\title{
PENGARUH INFLASI, INVESTASI DAN EKSPORT TERHADAP NILAI TUKAR RUPIAH DI SUMATRA UTARA PADA TAHUN 2001-2017
}

\author{
Emi Sundari ${ }^{1}$, M.Farid Adnan ${ }^{1}$, Vifian Turnip ${ }^{1}$, Yunia Lettisya Taringan ${ }^{1)}$ \\ 1) Program Studi Pendidikan Ekonomi, Fakultas Ekonomi Universitas Negeri Medan \\ E-mail: emisundari7010@gmail.com, faridadnan20@gmail.com, vifianturnip05@gmail.com, \\ Tyunia516@gmail.com
}

\begin{abstract}
Abstrak
Penelitian ini dilakukan untuk mengetahui pengaruh beberapa variabel independen seperti Inflasi, Investasi, dan Eksport terhadap variabel dependen yaitu Kurs (Nilai Tukar) di Sumatra Utara pada tahun 2001-2017. Penelitian ini mengunakan penelitian kuantitatif dengan mengunakan data sekunder sebagai acuan. Sampel penelitian ini mengunakan data time series tahun 2001-2017 yang diperoleh dari publikasi Badan Pusat Statistik (BPS) Sumatra Utara. Serta pengolahan data dengan menggunakan metode OLS (Ordinary Least Square) dan mengunakan alat pengolahan data menggunakan SPSS 22. Hasil dari penelitian ini adalah uji simultan menunjukkan bahwa Inflasi, Investasi dan Esport secara simultan atau bersama-sama berpengaruh terhadap Nilai Tukar Di Provinsi Sumatera Utara pada tahun 2001-2017. Hasil uji parsial menunjukkan bahwa variabel eksport berpengaruh negatif dan signifikan terhadap Nilai Tukar dan inflasi dan investasi berhubungan positif dan signifikan terhadap Nilai Tukar Di Provinsi Sumatera Utara. Variabel Inflasi, Investasi dan Ekspor mampu menjelaskan Nilai Tukar di Provinsi Sumatera Utara sebesar 73,1 persen. Serta sisanya 26,9 persen dipengaruhi variabel lain.
\end{abstract}

Kata Kunci : Inflasi, Investasi, Eksport, Nilai Tukar, Sumatera Utara. 


\section{PENDAHULUAN}

Nilai tukar merupakan salah satu indikator yang menunjukkan bahwa perekonomian suatu negara lebih baik dari negara lain. Semakin tinggi nilai tukar mata uang sebuah negara terhadap negara lain menunjukkan bahwa negara tersebut memiliki perekonomian yang lebih baik dari pada negara lain. Menurut Ismawati (2013) nilai tukar mata uang (exchange rate) atau sering disebut kurs yang diartikan sebagai harga mata uang sebuah negara, kurs digunakan sebagai salah satu harga yang terpenting dalam perekonomian terbuka mengingat pengaruh yang demikian besar bagi neraca transaksi berjalan maupun variabel - variabel makro ekonomi lainnya.

Mata uang yang dijadikan sebagai pembanding dalam tukar menukar mata uang adalah dollar Amerika Serikat, karena dollar Amerika merupakan salah satu mata uang yang kuat dan merupakan mata uang acuan bagi sebagian besar negara berkembang. Amerika Serikat merupakan partner dagang dominan di Indonesia sehingga ketika rupiah terhadap dollar AS tidak stabil, maka akan mengganggu perdagangan yang dapat menimbulkan kerugian ekonomi dikarenakan perdagangan dinilai dengan dollar.

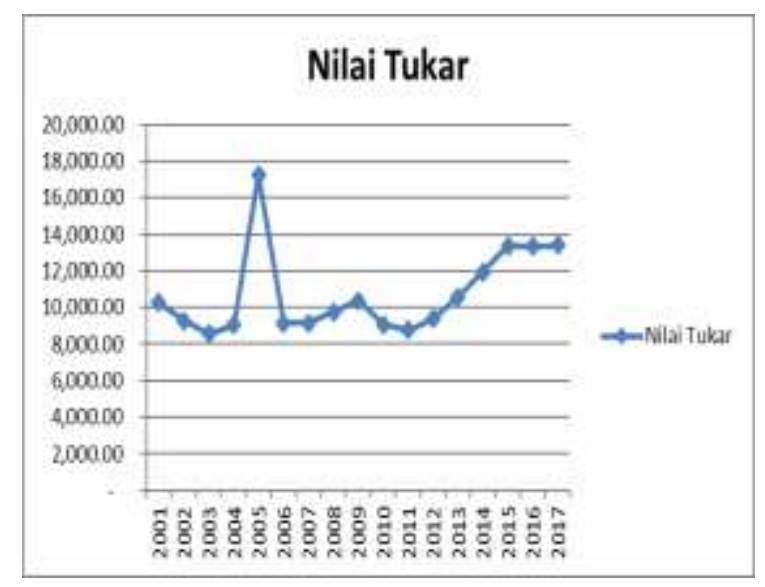

Sumber : Badan Pusat Statistik

(diolah)

Gambar 1.1. Perkembangan Nilai Tukar di Provinsi Sumatera Utara Tahun 20012017

Dari gambar di atas dapat diketahui bahwa pada tahun 2001-2003 nilai tukar Di Sumatra Utara mengalami penurunan kemudian naik secara drastis atau melonjak tinggi pada tahun 2005 yang hampir mencapai Rp 18.000 per dollar AS. Selanjutnya diikuti dengan penurunan Nilai Tukar di Sumatra Utara yang cukup drastis juga mencapai Rp 9.000 per dollar AS pada tahun 2006. Pada tahun 2007-2009 mengalami kenaikan nilai tukar turun kembali pada tahun 2010-2011 kemudiaan pada tahun 2012 sampai dengan tahun 2017 Nilai Tukar Di Sumatra Utaraa engalami kenaikkan nilai tukar terhadap dollar AS yang pada tahun 2017 mencapai Rp 13.398 per dollar AS. Berdasarkan data diatas dapat ditarik kesimpulan bahwa Terdepresiasinya nilai tukar mata uang domestik menyebabkan kekacauan pada berbagai bidang ekonomi.

Mengingat besarnya dampak dari fluktuasi kurs terhadap perekonomian, maka diperlukan suatu manajemen kurs yang baik, yang menjadikan kurs stabil, sehingga fluktuasi kurs dapat diprediksi dan perekonomian dapat berjalan dengan stabil. Apabila terjadi kegagalan pada manajemen kurs, maka hal tersebut mengakibatkan gangguan terhadap kestabilan perekonomian.

Penelitian mengenai pengaruh inflasi, investasi dan eksport terhadap nilai tukar rupiah per dollar AS sangat penting dilakukan, tujuannya ialah untuk mengetahui bagaimana hubungan dan seberapa besar pengaruh inflasi, investasi dan eksport dalam mempengaruhi pergerakan nilai tukar rupiah terhadap dollar AS. Pada akhirnya dapat diketahui kebijakankebijakan yang dapat diambil untuk menjaga kestabilan nilai tukar rupiah yang berkaitan dengan variabel Inflasi, Investasi Dan Eksport. Berikut perkembangan Inflasi, Investasi Dan Eksport terhadap Perkembangan Nilai Tukar Di Sumatra Utara pada tahun 2001-2017.

\begin{tabular}{|r|r|r|r|c|}
\hline \multirow{2}{*}{ Tahun } & Inflasi & \multicolumn{1}{c|}{ Investasi } & \multicolumn{1}{c|}{ Ekspor } & \multicolumn{1}{c|}{ Kurs } \\
\cline { 2 - 5 } & \multicolumn{1}{c}{$\%$} & Milyar Rp & Juta USD & Rp \\
\hline 2001 & 14,79 & $2.015,79$ & $2.294,80$ & $10.262,67$ \\
\hline 2002 & 9,59 & $2.011,59$ & $2.295,80$ & $9.261,17$ \\
\hline 2003 & 4,23 & $2.007,23$ & $2.296,80$ & $8.571,17$ \\
\hline 2004 & 6,80 & $2.010,80$ & $4.239,41$ & $9.031,92$ \\
\hline 2005 & 22,41 & $2.027,41$ & $4.563,80$ & $17.276,83$ \\
\hline 2006 & 6,11 & $2.012,11$ & $5.523,90$ & $9.141,25$ \\
\hline 2007 & 6,60 & $2.013,60$ & $7.082,90$ & $9.142,42$ \\
\hline 2008 & 10,72 & $2.018,72$ & $9.262,00$ & $9.771,67$ \\
\hline 2009 & 2,61 & $2.011,61$ & $6.460,00$ & $10.356,17$ \\
\hline 2010 & 8,00 & $2.018,00$ & $9.150,00$ & $9.078,25$ \\
\hline 2011 & 3,67 & $2.014,67$ & $11.880,00$ & $8.773,25$ \\
\hline 2012 & 3,86 & $2.015,86$ & $10.390,00$ & $9.373,58$ \\
\hline 2013 & 10,18 & $2.023,18$ & $9.600,00$ & $10.562,67$ \\
\hline 2014 & 8,17 & $2.022,17$ & $9.360,00$ & $11.944,50$ \\
\hline 2015 & 3,34 & $2.018,34$ & $7.750,00$ & $13.374,33$ \\
\hline 2016 & 6,34 & $2.022,34$ & $7.770,00$ & $13.329,83$ \\
\hline 2017 & 3,20 & $2.020,20$ & $9.220,00$ & $13.398,17$ \\
\hline
\end{tabular}

Sumber : Badan Pusat Statistik (diolah) 
Gambar 1.2. Inflasi, Investasi dan Eksport terhadap Perkembangan Nilai Tukar Di Sumatra Utara Tahun 2001- 2017

Berdasarkan Tabel di atas menunjukkan bahwa perkembangan Inflasi Di Sumatra Utara mengalami perkembangan turun dan naik pada tahun 2001-2017. Perkembangan inflasi yang tertinggi disumatra utara terjadi pada tahun 2005 sebesar 22,41 persen dan yang paling terendah pada tahun 2009 sebesar 2,61 persen. Kemudian Investasi yang terjadi Di Sumatra Utara tidak mengalami kenaikan ataupun penurunan. Sedangkan Eksport yang terjadi Di Sumatra Utara berdasarkan data menujukkan bahwa mengalami kenaikan pada tahun 2001 hingga pada tahun 2011 sebesar 2.294,80 US hingga $11.880,00$ US dan mengalami penurunan Eksport ditahun 2012-2016 sebesar 10.390,00 US hingga 7.770,00 dan pada tahun 2017 mengalami kenaikkan Eksport kembali sebesar 9.220,00 US.

Tingkat inflasi yang tinggi juga diikuti oleh pertumbuhan jumlah uang beredar yang tinggi akibat diperlukannya lebih banyak uang untuk kepentingan transaksi. Pertumbuhan jumlah uang beredar yang berlebihan dapat menimbulkan ketidak seimbangan dalam pasar uang dan memicu depresiasi nilai tukar. Jadi, dapat dikatakan bahawa perbedaan tingkat inflasi antar negara dapat mempengaruhi nilai tukar mata uangnya terhadap mata uang asing (Agustin, 2009). Hal ini tidak sesuai dengan penelitian Istiqamah \& Henny Amalia Septiana. (2018) yang menunjukan bahwa tingkat Inflasi berpengaruh negatif dan tidak signifikan terhadap Nilai Tukar Rupiah pada Dollar Amerika.

Investasi di suatu negara juga ikut mempengaruhi nilai tukar. Saat investasi meningkat maka nilai tukar akan mengalami apresiasi. Hal ini disebabkan karena tingginya investasi akan mendorong tingkat pertumbuhan ekonomi dan cadangan devisa suatu negara, sehingga dengan keadaan ekonomi yang baik maka diharapakan keadaan nilai tukar juga dalam keadaan stabil. Selain itu nilai Investasi yang meningkat akan menguatkan nilai mata uang domestik. Hal ini karena permintaan mata uang domestik akan meningkat, akibat banyak investor yang membutuhkan mata uang domestik untuk berinvestasi di negara tujuan. Sehingga dampak yang ditimbulkan ialah mata uang domestik akan terapresiasi.
NIAGAWAN Vol 8 No 2 Juli 2019

Ekspor yang semakin tinggi akan mengakibatkan nilai tukar semakin menurun yaitu terapresiasi. Hal ini tidak sesuai dengan penelitian Djulius dan Nurdiansyah (2014) yang menyatakan bahwa baik dalam jangka pendek maupun jangka panjang peningkatan ekspor akan diikuti oleh pelemahan nilai tukar yaitu mempunyai pengaruh positif terhadap nilai tukar. Berbeda juga dengan penelitian Agustin (2009) yang mengindikasikan bahwa variabel total nilai tukar tidak signifikan terhadao perubahan nilai tukar. Secara teoritis pengaruh ekspor terhadap nilai tukar mempunyai hubungan yang negatif dimana penguatan nilai tukar rupiah dengan semakin tingginya nilai ekspor. Penerimaan dari ekspor barang dan jasa oleh Negara lain yang semakin besar mengakibatkan jumlah valuta asing yang dimiliki suatu Negara semakin besar sehingga nilai tukar Rupiah terhadap Dolar AS cenderung menguat.

\section{METODE PENELITIAN}

Dalam penelitian ini, penelitian menggunakan data kuantitatif. Dimana data kuantitatif adalah data yang bersifat numerik atau angka (Lukman, 2007). Penelitian ini menggunakan studi literatur tentang pengaruh inflasi, investasi dan Eksport terhadap nilai tukar rupiah per dollar AS di Sumatra Utara. Penelitian ini menggunakan studi time series dari tahun 2001-2017. Serta pengolahan data dengan menggunakan metode OLS (Ordinary Least Square) dan dan alat pengolahan data menggunakan SPSS 22. Dalam penelitian ini data yang digunakan adalah data sekunder yang bersumber dari data-data statistik yang diterbitkan oleh Badan Pusat Statistik (BPS). Penelitian ini menggunakan model regresi berganda dengan metode OLS (Ordinary Least Square), dengan rumussan model penelitian sebagai berikut :

\section{$\mathbf{E R}=\alpha+\beta_{1} \mathrm{INF}+\beta_{2} \mathrm{INV}+\beta_{3} \mathrm{EKS}+\boldsymbol{\mu} \mathbf{i}$}

Untuk menstandarkan data, model di atas kemudian ditransformasikan ke dalam bentuk persamaan logaritma natural, persamaannya adalah sebagai berikut :

$$
\begin{aligned}
& \operatorname{LogER}=\alpha+\beta_{1} \operatorname{LogINF}+\beta_{2} \operatorname{LogINV}+\beta_{3} \\
& \operatorname{LogEKS}+\boldsymbol{\mu} \mathbf{i} \\
& \text { Keterangan } \\
& \text { ER = Nilai Tukar Rupiah/Dollar AS } \\
& \text { INF = Inflasi } \\
& \text { INV = Investasi } \\
& \text { EKS = Eksport }
\end{aligned}
$$




$$
\begin{array}{ll}
\alpha & =\text { Konstan / Intercept } \\
\mathrm{i} & =\text { Observasi ke } \mathrm{i} \\
\mu & =\text { Kesalahan yang }
\end{array}
$$

disebabkan oleh faktor acak

$$
\beta_{1}, \beta_{2}, \beta_{3} \quad=\text { Parameter Elastisitas }
$$

Metode pangkat kuadrat terkecil (OLS) diperkenalkan pertama kali oleh seorang ahli matematika dari jerman, yaitu Carl Fredich Gaus. Metode OLS adalah metode untuk mengestimasi suatu garis regresi dengan jalan meminimalkan jumlah kuadrat kesalahan dari setiap observasi terhadap garis tersebut (Kuncoro, 2003).

Sebelum melakukan interprestasi terhadap hasil regresi dari model penelitian yang akan digunakan, maka terlebih dahulu dilakukan pengujian terhadap data penelitian tersebut. Hal ini dilakukan untuk mengetahui apakah model tersebut dapat dianggap relevan atau tidak. Pengujian yang dilakukan melalui uji asumsi klasik yang meliputi uji normalitas, autokorelasi, heterokedastisitas, linieritas dan multikolinearitas, juga uji statistik yang meiliputi uji signifikansi parameter individu (uji statistik t), uji sinifikan simultan (uji statistik F), dan uji koefisien determinasi $\left(\mathrm{R}^{2}\right)$.

\section{Uji Asumsi Klasik}

Model regresi linear berganda yang baik adalah model yang terbebas dari asumsi-asumsi klasik yang meliputi uji normalitas, uji multikolinealitas, uji heterokedastisitas, dan uji autokorelasi.

\section{Analisis Statistik Inferensial}

\section{a. Uji Simultan (Uji F)}

Uji $F$ adalah pengujian yang bertujuan untuk mengetahui pengaruh simultan antara variabel bebas dengan variabel terikat. Untuk menguji hipotesis secara simultan digunakan rumus:

$$
F_{h}=\frac{R^{2} / k}{\left(1-R^{2}\right) /(n-k-1)}
$$

(sugiyono, 2010: 266)

\section{Keterangan:}

$$
\mathrm{R} \quad=\text { koefesien korelasi }
$$

$\mathrm{K} \quad=$ jumlah variabel

independen (terikat) sampel

$$
\mathrm{n} \quad=\text { jumlah anggota }
$$

\section{b. Uji Parsial (Uji t)}

Uji t adalah pengujian secara statistik untuk mengetahui apakah variabel independen secara parsial mempunyai
NIAGAWAN Vol 8 No 2 Juli 2019 pengaruh terhadap variabel dependennya.

$t_{\text {hitung }}=\frac{\operatorname{bi}(\beta i)}{S E(\beta i)}$

Dimana:

$t_{\text {hitung }}=$ nilai $\mathrm{t}$ hitung

bi $=$ koefesien regresi variabel

$\mathrm{SE}=$ standar eror regresi

$\mathrm{Bi} \quad=$ koefesien beta

\section{c. Analisis Koefisien Determinasi}

Analisis koefisien determinasi (R2) di gunakan untuk mengetahui seberapa besar presentase sumbangan pengaruh variabel independen secara serentak terhadap variabel dependen.

$$
R^{2}=\frac{I K R}{I K T} X 100 \%
$$

Keterangan:

$\mathrm{JKR}=$ Jumlah kuadrat regresi

$\mathrm{JKT}=$ Jumlah kuadrat total

\section{HASIL DAN PEMBAHASAN}

a. Uji Asumsi atau Uji Persyaratan Analisis

1. Uji Multikolinearitas

\begin{tabular}{|c|c|c|c|c|c|c|c|}
\hline \multirow[b]{2}{*}{ Model } & \multicolumn{2}{|c|}{$\begin{array}{c}\text { Unstan } \\
\text { dardize } \\
\text { d } \\
\text { Coeffic } \\
\text { ients }\end{array}$} & $\begin{array}{c}\text { Stand } \\
\text { ardize } \\
\text { d } \\
\text { Coeff } \\
\text { icient } \\
\text { s }\end{array}$ & & $\mathrm{S}$ & \multicolumn{2}{|c|}{$\begin{array}{l}\text { Collinea } \\
\text { rity } \\
\text { Statistic } \\
\text { s }\end{array}$} \\
\hline & B & $\begin{array}{l}\text { Std. } \\
\text { Err } \\
\text { or }\end{array}$ & Beta & $\mathrm{t}$ & $\begin{array}{l}\mathrm{i} \\
\mathrm{g} \\
\text {. }\end{array}$ & $\begin{array}{l}\text { Tole } \\
\text { ranc } \\
\mathrm{e}\end{array}$ & $\begin{array}{l}\mathrm{V} \\
\text { IF }\end{array}$ \\
\hline $\begin{array}{l}\text { (Constant } \\
1)\end{array}$ & $\begin{array}{r}3, \\
8 \\
8 \\
1 \\
, 0 \\
1 \\
4\end{array}$ & $\begin{array}{r}, 23 \\
1\end{array}$ &, 835 & $\begin{array}{r}5 \\
03 \\
0\end{array}$ & $\begin{array}{l}, \\
0 \\
0 \\
0 \\
, \\
0 \\
0 \\
0\end{array}$ &, 753 & $\begin{array}{l}1, \\
3 \\
2 \\
9\end{array}$ \\
\hline
\end{tabular}

Sesuai dengan metode penelitian, multikolinearitas dalam penelitian ini diuji dengan menggunakan VIF untuk mendeteksi adanya multikolinearitas, sebagai berikut:

Tabel. Variance Inflating Factor Coefficients $^{\mathrm{a}}$ 


\begin{tabular}{l|r|r|r|r|r|r|r|} 
LOG_IN & 1 & & & 4, &, & & 3, \\
VESTAS & 9 &, 04 & 1,178 & 71 & 0 &, 331 & 0 \\
I & 3 & 1 & & 2 & 0 & & 1 \\
& & & & & 0 & & 7 \\
LOG_EK & - & & & - &, & & 2, \\
SPORT &, 1 &, 08 & & 2, & 0 & & 5 \\
& 7 & 3 &,- 495 & 14 & 5 &, 387 & 8 \\
& 8 & & & 2 & 2 & & 2
\end{tabular}

a. Dependent Variable: LOG_NILAI TUKAR

Sumber: Data penelitian (diolah, 2019)

Berdasarkan Tabel diatas dengan kriteria bahwa jika nilai VIF $<10$ artinya di dalam model tidak terdapat multikolinearitas, maka dapat disimpulkan bahwa tidak terjadi permasalahan multikolinearity dalam data penelitian ini.

\section{Uji Autokorelasi}

Adapun output hasil perhitungan uji autokorelasi data menghasilkan nilai Durbin Watson hitung sebagai berikut:

Tabel. Uji Autokorelasi

\section{Uji Normalitas}

Adapun ouput hasil uji normalitas menggunakan Kolmogorov Smirnov Test diperoleh hasil sebagai berikut.

Tabel. Uji Normalitas

One-Sample Kolmogorov-Smirnov Test

\begin{tabular}{|ll|r|}
\hline & & $\begin{array}{r}\text { Unstandardize } \\
\text { d Residual }\end{array}$ \\
\hline $\mathrm{N}$ & 17 \\
Normal Parameters ${ }^{\mathrm{a}, \mathrm{b}}$ & Mean &, 0000000 \\
& Std. Deviation &, 04471664 \\
Most Extreme & Absolute &, 166 \\
Differences & Positive &, 166 \\
& Negative &,- 126 \\
Test Statistic & &, 166 \\
Asymp. Sig. (2-tailed) & &, $200^{\mathrm{c}, \mathrm{d}}$ \\
\hline
\end{tabular}

a. Test distribution is Normal.

b. Calculated from data.

c. Lilliefors Significance Correction.

d. This is a lower bound of the true significance.

Sumber: Data penelitian

Model Summa(cyiblah, 2019)

\begin{tabular}{|c|c|c|c|c|c|}
\hline Model & $\mathrm{R}$ & R Square & $\begin{array}{l}\text { Adjusted R } \\
\text { Square }\end{array}$ & 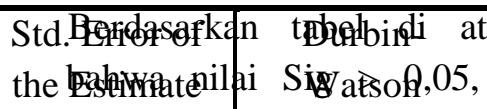 & $\begin{array}{l}\text { tas diketahui } \\
\text { maka dapat }\end{array}$ \\
\hline 1 &, $855^{\mathrm{a}}$ & ,731 & ,668 & disiphes & \\
\hline
\end{tabular}

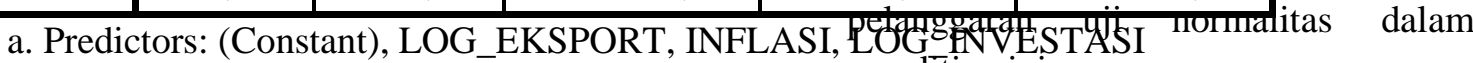

b. Dependent Variable: LOG_NILAI TUKAR penelitian ini.

Sumber: Data penelitian (diolah,

2019)

Berdasarkan hasil estimasi diperoleh nilai Durbin Watson (DW) hitung sebesar 1,400. Oleh karena $\mathrm{n}=17$ (banyak tahun) dan $\mathrm{k}=3$ (jumlah variabel bebas) dan membandingkan dengan tabel DW, maka diperoleh nilai dL sebesar 0,8968 dan du sebesar 1,7101. Selanjutnya dapat diputuskan dengan panduan sebagai berikut:

Tabel. Penentuan Autokorelasi Uji Durbin

\section{Watson}

Ada

itokorelasi positif diputuskan

2. Analisis Statistik Inferensial

a. Analisis Regresi Linear Berganda

Nilai koefisien mampu menunjukkan besarnya proporsi perubahan besaran permintaan Nilai Tukar dalam satu satuan masing-masing variabel. Adapun koefisien masing-masing variabel dapat dilihat dalam persamaan regresi penelitian seperti terlihat pada model berikut :

NILAI TUKAR(Y) $=3,881+0,014$ (INF) $+0,193$ (INV) - 0,178 (EKS)

Berdasarkan koefisien diatas, maka dapat dijelaskan sebagai berikut:

a.Konstanta sebesar 3,881 menunjukkan Ada bahwa jika variabel bebas seperti tokorelasi Inflasi, Investasi dan Ekspor adalah negatif konstan, maka Nilai Tukar di Sumatra negatif Utara akan tetap sebanvak 3.881

0 $\mathrm{d}_{\mathrm{L}}$

$\mathrm{d}_{\mathrm{u}}$

Oleh karena 0,8968 1,7101 ıda diantara du dan 4-du, maka dapat disimpulkan bahwa tidak ada permasalahan autokorelasi dalam penelitian ini.

$$
4-d_{\mathrm{u}} \quad \text { l. } 4-\mathrm{d}_{\mathrm{L}} \quad 4
$$

2,2899 ke 3.1032 isi scuesal 1 r......, ma... ...............ingkatkan Nilai Tukar di Sumatra Utara sebesar 0,014 persen.

c.Setiap kenaikan Investasi sebesar 1 persen, maka akan meningkatkan Nilai Tukar di Sumatra Utara sebesar 0,193 persen. 
d. Setiap kenaikan Ekspor sebesar 1 persen, maka akan Menurunkan Nilai Tukar di Sumatra Utara sebesar 0,178 persen.

b. Uji Simultan (Uji F)

Adapun output perhitungan hasil uji simultan dapat dilihat pada tabel berikut ini:

Tabel. Uji Simultan ANOVA $^{\mathrm{a}}$

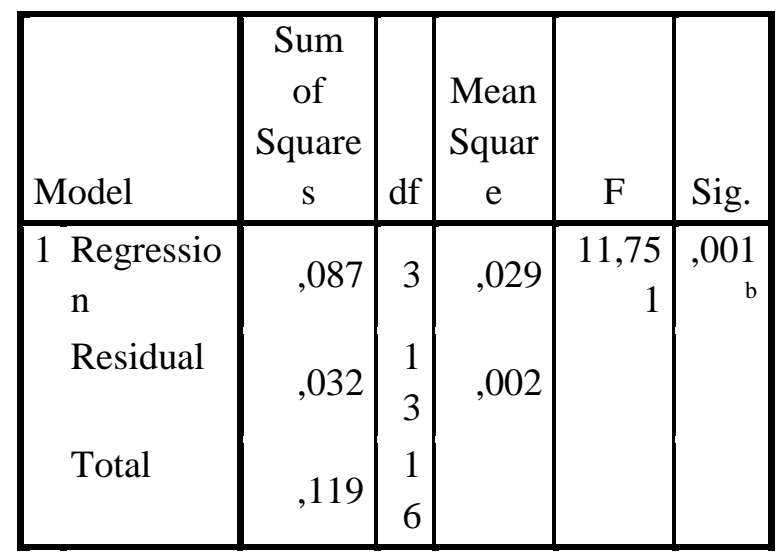

a. Dependent Variable: LOG_NILAI TUKAR

b. Predictors: (Constant), LOG_EKSPORT,

INFLASI, LOG_INVESTASI

Sumber: Data penelitian (diolah, 2019)

Berdasarkan tabel di atas diketahui bahwa nilai $\mathrm{F}$ hitung sebesar $11,751>\mathrm{F}$ tabel $(\alpha$ $=5 \%, \mathrm{db} 1=3, \mathrm{db} 2=\mathrm{n}-\mathrm{k}-1=17-3-1=13$ ) sebesar 3,41 dan perolehan nilai Sig. sebesar $0.001<0.05$, sehingga Ho ditolak. Artinya Inflasi, Investasi dan Esport secara simultan atau bersama-sama berpengaruh terhadap Nilai Tukar Di Provinsi Sumatera Utara pada tahun 20012017. pada taraf alpha 5 persen.

\section{c. Uji Parsial (Uji t)}

Adapun hasil perhitungan uji parsial dalam penelitian ini adalah sebagai berikut:

Tabel. Hasil Uji Hipotesis Coefficients $^{\mathrm{a}}$

\begin{tabular}{|c|c|c|c|c|c|c|c|}
\hline \multirow[b]{2}{*}{ Model } & \multicolumn{2}{|c|}{$\begin{array}{c}\text { Unstan } \\
\text { dardize } \\
\text { d } \\
\text { Coeffic } \\
\text { ients }\end{array}$} & $\begin{array}{c}\text { Stand } \\
\text { ardize } \\
\mathrm{d} \\
\text { Coeff } \\
\text { icient } \\
\mathrm{s}\end{array}$ & & $\mathrm{S}$ & \multicolumn{2}{|c|}{$\begin{array}{l}\text { Collinea } \\
\text { rity } \\
\text { Statistic } \\
\text { s }\end{array}$} \\
\hline & B & $\begin{array}{l}\text { Std. } \\
\text { Err } \\
\text { or }\end{array}$ & Beta & $\mathrm{t}$ & $\begin{array}{l}1 \\
g\end{array}$ & $\begin{array}{c}\text { Tole } \\
\text { ranc } \\
\mathrm{e}\end{array}$ & $\begin{array}{l}\mathrm{V} \\
\mathrm{IF}\end{array}$ \\
\hline $\begin{array}{l}1 \text { (Constant } \\
\text { ) }\end{array}$ & $\begin{array}{r}3 \\
8 \\
8\end{array}$ & $\begin{array}{r}, 23 \\
1\end{array}$ & & $\begin{array}{r}16 \\
, 8 \\
25\end{array}$ & $\begin{array}{l}0^{\prime} \\
0\end{array}$ & & \\
\hline
\end{tabular}

NIAGAWAN Vol 8 No 2 Juli 2019

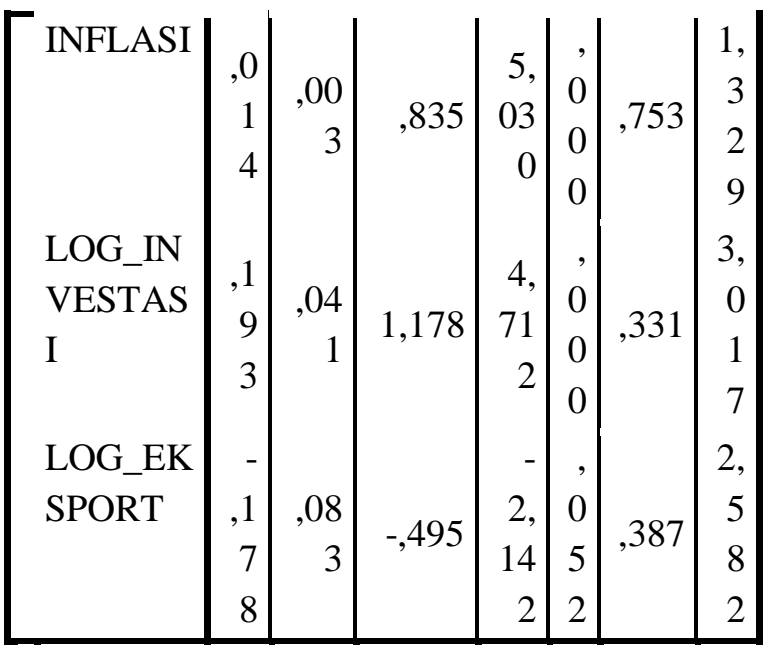

a. Dependent Variable: LOG_NILAI TUKAR

Sumber: Data penelitian (diolah, 2019)

Berdasarkan Tabel diatas, dapat diperoleh kesimpulan sebagai berikut:

a. Variabel Inflasi berpengaruh Positif dan signifikan terhadap Nilai Tukar di Provinsi Sumatera Utara dengan perolehan nilai $\mathrm{t}_{\text {hitung }}$ sebesar $5,030>\mathrm{t}$ tabel $(\alpha=5 \%, d b=n-k=17-4=13)$ sebesar 1.77093 dan perolehan nilai Sig $0,000<0,05$, maka Ho ditolak pada taraf alpha 1 persen.

b. Variabel Investasi berpengaruh positif dan signifikan terhadap Nilai Tukar di Provinsi Sumatera Utara dengan perolehan nilai $\mathrm{t}_{\text {hitung }}$ sebesar 4,712 >t tabel $(\alpha=5 \%, \mathrm{db}=\mathrm{n}-\mathrm{k}=17-4=13)$ sebesar 1.77093 dan perolehan nilai Sig $0,000<0,05$, maka Ho ditolak pada taraf alpha 1 persen.

c. Variabel Esport berpengaruh negatif dan signifikan terhadap Nilai Tukar di Provinsi Sumatera Utara di Provinsi Sumatera Utara dengan perolehan nilai $\mathrm{t}_{\text {hitung }}$ sebesar 2,142 >t tabel $(\alpha=5 \%, \mathrm{db}=\mathrm{n}-\mathrm{k}=17-4=13)$ sebesar 1.77093 dan nilai Sig $-0,052<$ 0,05 , maka Ho diterima pada taraf alpha 10 persen.

\section{d. Analisis Koefisien Determinasi}

Adapun hasil perhitungan koefisien determinasi dalam penelitian adalah sebagai berikut : 
Tabel. Koefisien Determinasi Model Summary ${ }^{\mathrm{b}}$

\begin{tabular}{|l|c|c|c|c|c|}
\hline $\begin{array}{l}\text { Mod } \\
\mathrm{el}\end{array}$ & $\mathrm{R}$ & $\begin{array}{c}\text { Squar } \\
\mathrm{e}\end{array}$ & $\begin{array}{c}\text { Adjuste } \\
\mathrm{d} \mathrm{R} \\
\text { Square }\end{array}$ & $\begin{array}{c}\text { Std. } \\
\text { Error } \\
\text { of the } \\
\text { Estimat } \\
\mathrm{e}\end{array}$ & $\begin{array}{c}\text { Durbi } \\
\mathrm{n}-\end{array}$ \\
$\begin{array}{l}\text { Watso } \\
\mathrm{n}\end{array}$ \\
\hline 1 &, 855 &, 731 &, 668 &, 04961 & 1,400 \\
\hline
\end{tabular}

a. Predictors: (Constant), LOG_EKSPORT, INFLASI, LOG_INVESTASI

b. Dependent Variable: LOG_NILAI TUKAR

Sumber: Data penelitian (diolah, 2019)

Berdasarkan tabel diatas diketahui bahwa nilai nilai $R 2$ squared sebesar 0,731 . Hal ini menunjukkan bahwa variabel Inflasi, Investasi, dan Ekspor mampu menjelaskan Nilai Tukar di Provinsi Sumatera Utara sebesar 73,1 persen. Serta sisanya 26,9 persen dipengaruhi variabel lain yang tidak diteliti dalam penelitian ini.

\section{Pembahasan Variabel Penelitian \\ a. Variabel Inflasi terhadap nilai tukar di Provinsi Sumatera Utara}

Berdasarkan hasil uji statistik, diperoleh hasil bahwa terdapat pengaruh yang positif dan signifikan inflasi terhadap nilai tukar rupiah di Provinsi Sumatera Utara pada Tahun 2001-2017. Hasil penelitian ini mendukung hasil penelitian sebelumnya, Istiqomah (2013) menjelaskan bahwa Inflasi berpengaruh terhadap Nilai tukar rupiah di Indonesia. Nurul Hazizah, dkk (2017) bahwa inflasi berpengaruh positif dan signifikan terhadap nilai tukar.

Pengaruh positif Inflasi sesuai dengan teori paritas daya beli. Naiknya harga barang mendorong terjadinya inflasi. Inflasi menyebabkan uang akan berkurang nilainya, dalam artiaan berkurangnya barang dan jasa yang dapat dibeli dan berkurangnya jumlah mata uang lain yang dapat diperoleh. Sehingga hal ini mendorong rupiah terus terdepresiasi karena adanya inflasi. Jika tingkat harga (IHK) naik atau terjadi inflasi maka nilai rupiah yang di butuhkan untuk mendapatkan dollar AS akan terdepresiasi. Hal ini dapat memperburuk kestabilan nilai tukar rupiah, sehingga otoritas moneter perlu menjaga kestabilan tingkat harga. Oleh karena itu, kebijakan moneter dengan pengendalian inflasi harus menjadi salah satu perhatian utama negara Indonesia.
NIAGAWAN Vol 8 No 2 Juli 2019

Selisih inflasi Indonesia dan Amerika berpengaruh positif dan signifikan terhadap perubahan kurs Rupiah terhadap Dollar Amerika Serikat. Artianya apabila perbedaan inflasi meningkat akan meningkatkan perubahan kurs Rupiah atas Dollar Amerika Serikat. Apabila Inflasi domestik yang meningkat akan mengakibatkan kurs terdepresiasi sebaliknya apabilai inflasi luar negeri meningkat maka akan mengakibatkan kurs Rupiah terapresiasi karena Inflasi yang tinggi disuatu Negara akan menyulitkan kalkulasi perencanaan bisnis sehingga berdampak buruk bagi aktifitas perekonomian dalam jangka panjang (Pratiwi dan Santoso, 2012). Inflasi yang terjadi mengakibatkan daya beli masyarakat untuk memenuhi kebutuhan semakin rendah karena harga barang dan jasa mengalami kenaikan secara terus menerus dimana ketika harga barang dan jasa yang terus meningkat tersebut akan mengakibatkan impor barang Amerika juga meningkat sehingga permintaan valas Amerika Serikat meningkat.

\section{b. Variabel Investasi terhadap nilai tukar di Provinsi Sumatera Utara}

Berdasarkan hasil uji statistik, diperoleh hasil bahwa terdapat pengaruh yang positif dan signifikan investasi terhadap nilai tukar rupiah di Provinsi Sumatera Utara pada Tahun 2001-2017. Hasil penelitian ini mendukung hasil penelitian sebelumnya, Istiqomah (2013) menjelaskan bahwa Investasi berpengaruh terhadap Nilai tukar rupiah di Indonesia.

Terjadinya hubungan positif antara PMA dengan nilai tukar rupiah terhadap dollar AS. Hal ini disebabkan oleh, PMA yang masih menggunakan input barang setengah jadi dan teknologi impor dalam proses produksinya. Hal tersebut menyebabakan adanya impor besarbesaran terhadap barang setengah jadi dan teknologi oleh para investor PMA. Kegiatan tersebut menyebabkan kurs rupiah terdepresiasi, karena permintaan mata uang dollar AS akan meningkat, meningkatnya permintaan tersebut menyebabkan rupiah terdepresiasi terhadap dollar AS.

\section{c. Variabel Ekspor terhadap nilai tukar} di Provinsi Sumatera Utara

Berdasarkan hasil uji statistik, diperoleh hasil bahwa terdapat pengaruh yang negatif dan signifikan Eksport terhadap nilai tukar rupiah di Provinsi Sumatera Utara pada Tahun 2001-2017. Hasil penelitian ini mendukung hasil penelitian sebelumnya, Nurul Hazizah, dkk (2017) bahwa 
Eksport berpengaruh negatif dan signifikan terhadap nilai tukar.

Ekspor yang mempunyai pengaruh negatif dan signifikan terhadap nilai tukar Rupiah atas dolar Amerika Serikat berlawanan arah berarti bahwa shock yang terjadi pada ekspor akan direspon negative oleh nilai tukar. Dimana ekspor yang semakin tinggi akan mengakibatkan nilai tukar semakin menurun yaitu terapresiasi. Secara teoritis pengaruh ekspor terhadap nilai tukar mempunyai hubungan yang negatif dimana penguatan nilai tukar rupiah dengan semakin tingginya nilai ekspor. Penerimaan dari ekspor barang dan jasa oleh Negara lain yang semakin besar mengakibatkan jumlah valuta asing yang dimiliki suatu Negara semakin besar sehingga nilai tukar Rupiah terhadap Dolar AS cenderung menguat.

Menurut (Miranti Sedyaningrum, Suhadak Nila, Firdausi Nuzula, 2016) menyatakan Nilai tukar Rupiah terhadap Dollar AS akan menguat ketika ekspor mengalami kenaikan dan begitu pula sebaliknya nilai tukar Rupiah akan melemah ketika ekspor menurun. Menurut Murni (dalam Miranti Sedyaningrum, Suhadak Nila, Firdausi Nuzula, 2016) mengatakan kegiatan ekspor dan impor akan mempengaruhi jumlah permintaan mata uang suatu Negara. Kegiatan ekspor akan mengakibatkan naiknya permintaan mata uang Negara pengekspor sehingga mata uang akan menguat. Kegiatan ini akan mengakibatkan naiknya permintaan mata uang Negara pengimpor sehingga nilai mata uang dalam negeri akan melemah. Menurut (Eun, Resnick dan sabherwal 2013) mengatakan apabila tingkat ekspor suatu Negara lebih tinggi, maka permintaan terhadap mata uang Negara itu bertambah lebih cepat dari penawaranya dan oleh karenanya nilai mata uang Negara itu naik.

\section{KESIMPULAN DAN SARAN}

Berdasarkan uraian diatas maka dapat ditarik kesimpulan sebagai berikut: (1) Secara simultan Inflasi, Investasi dan Ekspor berpengaruh terhadap Nilai Tukar di Provinsi Sumatera Utara pada tahun 2001-2017. (2) Secara parsial disimpulkan bahwa : (a) Variabel Inflasi berpengaruh positif dan signifikan terhadap Nilai Tukar di Provinsi Sumatera Utara. (b) Variabel Investasi berpengaruh Positif dan signifikan terhadap Nilai Tukar di Provinsi Sumatera Utara. (c) Variabel Ekspor berpengaruh negatif dan signifikan Nilai Tukar di Provinsi Sumatera Utara. (3) Variabel Inflasi, Investasi dan Ekspor mampu menjelaskan Nilai Tukar di Provinsi Sumatera Utara sebesar 73,1 persen. Serta sisanya 26,9 persen dipengaruhi variabel lain yang tidak diteliti dalam penelitian ini. (4) Hasil penelitian ini menunjukkan bahwa variabel yang signifikan dan paling dominan terhadap Pertumbuhan Ekonomi di Provinsi Sumatera Utara adalah Investasi.

Adapun saran pada penelitian ini adalah (1) Pemerintah agar melakukan usaha-usaha agar nilai tukar tetap terkendali. Upaya ini harus didukung dengan menjaga ke stabilan tingkat inflasi. (2) Dalam penelitian selanjutnya, perlu adanya penambahan variabel makroekonomi lain yang kemungkinan mempengaruhi nilai tukar rupiah agar model estimasi dapat lebih dipercaya mampu menjelaskan nilai tukar rupiah. (3) Bagi eksportir diharapkan dapat meningkatkan volume ekspornya karena dalam hasil penelitian ekspor berpengaruh signifikan terhadap nilai tukar Rupiah. Dengan ditemukannya bahwa bila inflasi meningkat maka nilai tukar rupiah juga terdepresiasi, maka kebijakan yang dapat diambil adalah dengan menjaga kestabilan inflasi yang terjadi di masyarakat,sehingga harga barang-barang tidak meningkat terlalu tinggi. Maka nilai tukar rupiah akan berada dalam keadaan stabil dan inflasi pun demikian.

\section{REFERENSI}

Agustin, Grisvia. 2009. Analisis Paritas Daya Beli Pada Kurs Rupiah terhadap Dolar Amerika SErikat Periode September 1997 -Desember 2007 dengan Menggunakan Metode Error Correction Model. Jurnal IESP Vol 1, No, 1; Fakultas Ekonomi Universitas Negeri Malang.

Badan Pusat Statistik. Sumatera Utara Dalam Angka. BPS Provinsi Sumatera Utara. 2001-2017

Djulius dan Nurdiansyah. 2014. Keseimbangan Jangka Panjang dan Jangka Pendek Nilai tukar Rupiah terhadap dolar Amerika. Journal Trikonomika Vol 13 No 1. Fakultas Ekonomi Universitas Pasundan Bandung.

Hazizah, Nurul. 2017. Pengaruh JUB, Suku Bunga, Inflasi, Ekspor dan Impor terhadap Nilai Tukar Rupiah atas Dollar Amerika Serikat. e-Journal 
Ekonomi Bisnis dan Akutansi. Volume

IV (1) : 97-103.

Ismawati, Lina dan Beni Hermawan. 2013.

Pengaruh Kurs Mata Uang Rupiah Atas

Dollar AS, Tingkat Suku Bunga

Sertifikat Bank Indonesia dan Tingkat

Inflasi terhadap Indeks Harga Saham

Gabungan. Jurnal Ekono Insentif Kopwil4.Vol.7. No. 2.

Istiqamah \& Henny Amalia Septiana. 2018.

Pengaruh Inflasi Dan Suku Bunga

Terhadap Nilai Tukar Rupiah Pada

Dollar Amerika. Jurnal Spread. Volume

8 Nomor 1. Hal 19-29.

Istiqomah. 2013. Pengaruh Inflasi Dan Investasi

Terhadap Nilai Tukar Rupiah. Ikatan

Sarjana Ekonomi Indonesia Vol. 2 No. 1

Kuncoro, Mudrajad. 2003. Metode Riset Untuk

Bisnis dan Ekonomi. Jakarta: Erlangga.

Lukman. 2007. Modul I praktikum statistik Lab.

Alat Analisis Kuantitatif semester Ganjil tahun ajaran akademik 2007/2008.

Jakarta : UIN.

Musyaffa, Arfidan Sabiq \& Sri Sulasmiyati.

2017. Pengaruh Jumlah Uang Beredar,

Inflasi Dan Suku Bunga Terhadap Nilai

Tukar Rupiah Terhadap Dollar (Studi

Pada Bank Indonesia Periode 2011-

2015). Jurnal Administrasi Bisnis

(JAB).Vol. 50 No. 4. Hal 19-24.

Pratiwi dan Santoso, 2012, Analisis Perilaku

Kurs Rupiah (IDR) Terhadap Dollar

Amerika(USD) pada Sostem Kurs

Mengambang Bebas di Indonesia

Periode 1997.3-2011.4 (Aplikasi

pendekatan Keynesian Sticky Price

Model). Diponegoro Journal of

Economics Vol 1. No.1. Hal.3.

Sugiyono. 2010. Metode Penelitian Pendidikan

Pendekatan Kuantitatif, kualitatif, dan $R \& D$. Bandung: Alfabeta. 